\title{
Local Self-Governments in Hungary: Recent Changes through Central European Lenses
}

\author{
Csaba Lentner \\ National University of Public Service, Faculty of Science of Public Governance and \\ Administration, Public Finance Research Institute, PADA Foundation - National \\ Bank of Hungary, Budapest, Hungary \\ lentner.csaba@uni-nke.hu \\ https://orcid.org/0000-0003-2241-782X \\ Szilárd Hegedűs \\ National University of Public Service, Faculty of Science of Public Governance \\ and Administration, Public Finance Research Institute, Budapest Business School, \\ Budapest, Hungary \\ hegedus.szilard@uni-bge.hu \\ https://orcid.org/0000-0002-0286-1715
}

Received: 14. 6. 2019

Accepted: 3. 10. 2019

\section{ABSTRACT}

This article provides an overview of the regulatory environment of the Hungarian system of local self-government based on the methods of legal dynamics and economic analyses in a historical perspective tracing events back to the aftermath of World War II. The starting point of the analysis is 1947, the launching of soviet type command economy in Hungary. Next is a detailed study of the regulation and evolution of local selfgovernment since its beginnings in the early 1990s following the change of regime, with a brief international outlook on the post-soviet countries surrounding Hungary. In our economic analysis, emphasis is placed on the period following Hungary's accession to the European Union, a period that held out considerable opportunities for Hungarian local self-governments, but ultimately evolved into bankruptcy. The article presents detailed reasons for the atypical nature of Hungarian local self-government indebtedness and the factors underlying this unfavourable process. Further on, the procedure of debt consolidation and the essential elements of the new regulatory environment created after 2011 are described. In a brief international comparison, debt portfolio developments are analysed through the examples of Slovenia, Poland, Slovakia and the Czech Republic as analogue Central European countries, in order to provide further proof of the atypical financial management of Hungarian local selfgovernments, i.e. non-compliance with the rules and the not always solid budgetary discipline. The focus of the research underlying this paper is the impact the Hungarian regulation of self-governments had on the financial sustainability of local self-governments' financial management. 
The study confirmed the initial hypothesis that the business management rules set out with insufficient prudence, deficiencies in the control system, and excessive borrowing in foreign exchange led to bankruptcy of a number of local self-governments and consequently jeopardised the proper provision of public services.

Keywords: comparative analysis, local self-government, indebtedness, public finances, Hungary, Central European economies

JEL: H7O, H71, H72

\section{Introduction}

As local self-government systems provide the local dimension of performing public service tasks, they have a powerful impact on the living standards of the population, and consequently, the stable operation of local self-governments is of macro-economic interest. This paper gives an overview of the history of local self-government in Hungary from the socialist era to date, with special focus on the main events after the change of regime, in the context of other Central European countries that have undergone a similar development. The purpose of this paper is to highlight Hungary among the countries of similar history and similar modernisation efforts, and to direct the attention to a peculiar local self-government financing practice.

In the period of command economy and during transition to a market economy, the Hungarian practice of local self-government adjusted to the operational principles of the Soviet Union, which had a profound impact on the region, and then after 1990, to those of the European Union. Similarly to other countries of the Central European region, after in Hungary transformation of the local self-government system after the change of regime was based on the European Charter of Local Self-Government, and these principles were also enforced during the 2011 reform. Since the change of regime, there have been two statutes in effect with both similarities and differences in regulatory content. Based on all these, the hectic changes in the financial situation of Hungarian local self-governments promise an exciting research topic this paper undertakes to present.

\section{Literature review and methods}

\subsection{Literature review}

The maintenance of operability for the public finances of the central government and of local self-governments was in the limelight for political decisionmakers in the initial years that followed the $2007-2008$ crisis.

According to the classical literature tenet, a fiscal crisis takes place when for certain reasons the state loses the opportunity of financing from the market, or when deficit financing runs into costs that paralise its fundamental opera- 
tion. This is characteristically caused by the unreliability of the government (Cordes et al. 2015). In the past decades this crisis has also become permanent in the case of local self-governments given substantial economic autonomy, as they have increasingly been raising the required funds from the banking, and more specifically from the bond market.

The government units, regions and local self-governments below the central level are characteristically less likely to go bankrupt than sovereign states, although local self-governments' mass bankruptcy may trigger problems on a national level. The reasons for fiscal crises in local and regional units can be divided into two major groups: central and local factors.

The central factors include deregulation, insufficient transparency conditions, transfer of the fiscal crisis situation and an overall macro-economic crisis. During deregulation local self-governments are given the opportunity to finance their operative and investment activities from the financial markets. This is restricted by the application of fiscal rules and by the market's disciplinary power. Kornai (2004) and Beck et al. (2016) think that if subnational institutions cannot expect help from the central government, their budgetary limit remains hard, and this contributes to the disciplinary force of the market. However, it should be added that the inoperability of local self-governments jeopardise the security of the people living in the community and the supply of public services, and thus it is in the fundamental interest of both the central and the local authorities to consolidate such a situation, and instead of enforcing the disciplinary power of the market, which may lead to the escalation of social conflicts, to use the opportunity of rescue by the government.

The absence of transparency, which develops over a period of many years, may primarily arise from differences in the accounting rules and the possibility or impossibility of their consolidation. Compliance with the budgetary regulations have accounting aspects that may gloss over any fiscal crisis situation (de Vicente Lama, 2017). This can be offset by a consistent application of accrual-basis accounting, by the consistent enforcement of supervisory powers, and by efficient business management, which may hardly leave any "skeletons" in the business system.

A vertical imbalance evolves when the expenses exceed the tax revenues of the central budget, while the local self-governments make surpluses from their local tax revenues. In this case the central budget reduces the imbalance by cutting back on support. This phenomenon took place, for instance in Hungary as a result of the convergence trajectory adjustment package announced in the autumn of 2006, and in Italy in the early 1970s, when the central government reduced the share in tax revenues was reduced (Hagen et al. 2000) to the detriment of the local self-governments.

Local crisis factors include the following: a crisis situation in the structure of the local economy, effects of local politics, indebtedness by the local self-government's institutions or their unsecured business management, and financ- 
ing their mostly unproductive investment projects from risky loans (foreign exchange loans, short-term credits).

The taxes collected by local self-governments heavily depend on the performance of the local economy, and thus the industrial structures may cause high exposure in the local budget. As a characteristic cause, a given region's economy may be insufficiently resilient to shocks, as it is typically specialised in one particular industry. A characteristic example includes Detroit, the city that built its economy on the automotive industry, and went bankrupt when the latter deteriorated (Jacoby, 2016).

The local political élite "inherently" endeavours to maximise the number of votes in order to get re-elected, and this may influence the level of indebtedness either by excessive current expenses or by the implementation of showcase investments without internal resources. This may also be determined by the ideological background. De Vicente Lama (2017) established a statistical correlation between the party affiliations of local self-governments and the extent of their indebtedness.

If the business management of an organisation operating with the participation of a local self-government is insufficiently transparent, the owner can influence the debt portfolio of the local self-government or subnational organisation (Hagen et al. 2000). The relevant international research also apply to the atypical business management performed by Hungarian local self-governments after the change of regime.

\subsection{Material and methods}

In this paper the financial regulation of Hungarian local self-governments and its evolution are analysed in an interdisciplinary approach. The numerical data used in this paper have been obtained from the databases of OECD and the National Bank of Hungary. The debt portfolio was studied using the time-line analysis in a breakdown by foreign exchange. The effect of exchange rated on debt was also taken into consideration on the basis of the official mean rate quoted by the National Bank of Hungary.

The other methodological approach applied in this study included a comparison of statutory regulations. The financial regulation applicable to Hungarian local self-governments, including financing and debt rules, has been analysed. In addition, analyses were also conducted in legal dynamics for this study, in order to evaluate changes in the statutory environment. 


\section{The Hungarian local self-government system between 1949 and 2011}

\subsection{The Hungarian local self-government system in the period of socialist planned economy}

In 1947 Hungary was included among the countries of the socialist bloc, and its public administration and public law regime was adjusted to the soviet pattern. Following the soviet model, local self-governments were called "councils". In the period of the council system, the soviet-style constitution "only recognized municipalities' right to self-government to a limited extent, and local self-government autonomy was essentially eliminated. In the centralised state organisation, municipalities were considered as decentralised local units of the central government authority and exercised its power similarly to the soviet model. Thus the entry into force of Act I of 1950 practically eliminated local self-government. One of the preconditions of self-government is the independent income generation opportunity of municipalities, and this was terminated by the entry into force of Act I of 1950 (Gergely, 2005).

As to the structure of the municipal system, the first council act divided these units into county councils, district councils, city councils and village councils. Similarly to the National Assembly, the autonomy of county councils was terminated, as they were practically brought under the control of the Hungarian Socialist Party, however, it exercised compliance supervision and had supervisory functions over district, city and village councils. County councils had a role in the planning, implementation and coordination of local projects and public investments. However, they were unable to influence central plans, and could not adequately support economic and social developments as the system was heavily centralised on a national level. Pursuant to the act, the tasks and competences of district councils included the coordination of villages and cities. The system was hierarchically built just as in the Soviet Union.

The new council act that entered into force in 1971 identified local self-governments as public administration organisations, stressing the representation of people, however, the latter was merely formal. The structure was characterised by the termination of subordination between councils, and district councils were liquidated, so the formerly three-tier system became two-tier.

Local self-government was also limited financially at every level, as they did not have any income of their own. In another perspective, local self-governments were not authorised to perform asset management, as councils were only entitled to act as trustees.

1 See: Act XX of 1949 on the Constitution of the People's Republic of Hungary, Articles 29-35 on the local organisations of the government authority. 


\subsection{The Hungarian local self-government system after the change of regime}

After the regime change, the legislators endeavoured to establish a modern, operable and autonomous system of local self-governments. To this end, the principles laid down in the European Charter of Local Self-Government (hereinafter: Charter) were taken into account. The Charter professes and recognises the principles of fiscal decentralisation and gives guidance to the countries in them. ${ }^{2}$ The central element regulating transposition was Act LXV of 1990, which regulated local self-government operation. The most important criterion of the statute containing a total of 118 articles is that it regulates the legal and economic foundations of local self-governments, namely the right to self-government. Its provisions were repealed gradually between 1st January 2012 and 2nd October 2014.

The first act on local self-governments and the sectoral laws established the mandatory duties and competence of local self-governments. After articulating local self-governments' mandatory tasks and powers, the National Assembly ensured the financial conditions required for their performance, decided on the amount and disbursement method of budgetary support and included all these in Chapter IX of the budget act at any time.

In addition to the Charter, in line with the spirit of the times, the principles of the New Public Management were also taken into consideration, as manifest in the freedom of organisation and service solicitation. This opportunity frequently resulted in the outsourcing of mandatory tasks previously falling within the competence of local self-governments to companies operating on a market basis (e.g. holding and operation of municipal assets and the provision of public utility services). All this meant that local self-governments were given carte blanche in the elaboration of their service organisation solutions, as they were only responsible for the organisation and not the actual performance of the duties. Law granted municipalities the right to independently develop their organisational structure and operational procedures, to freely dispose of the local self-government's assets, to manage their income independently, and to provide for the performance of voluntarily undertaken and mandatory municipal tasks. The regulation also allowed them to undertake business activities. ${ }^{3}$ This created additional opportunity for the local self-government system to freely associate with other local self-governments, to form with regional and national interest representation organisations to represent and protect their interests, to cooperate with foreign local self-governments within the scope of their tasks and competences, and to join international associations of local self-governments.

2 Fiscal decentralisation depends on numerous variables. One of the empirical research approach to this matter was examined by Benčina, J. and Mrdža Kovačič, A. (2013). The statistical correlations between the quality of governance and decentralisation was studied by Umek (2014).

3 In practice, instead of this organisational form, they were implemented as business associations, primarily due to the difficulty of accounting reconciliation. 
The first act on local self-governments ensured independence in earning and using incomes, and also regulated the incomes of local self-governments. They covered the costs of performing their mandatory and voluntary tasks from their own incomes, assigned central taxes, granted revenues, central budgetary contributions and aids. Their own incomes included local taxes ${ }^{4}$, revenues for capital formation and liquid assets received.

The specific part of the income tax collected by the central tax authority from the public administration section of the local self-governments could be termed assigned central tax, however, the part returned to local self-governments gradually decreased. Personal income tax, which was first imposed in 1988, was still completely a council income, but later on, after the change of regime 80 , and then 50 per cent of it was transferred to the central budget. By 2013 the ratio returned to local self-governments in the second tax year preceding the budget year had already dropped to a mere 8 per cent, and further 32 per cent was allocated to local self-governments depending on their level of development. ${ }^{5}$ Of all property taxes, only vehicle tax was paid to the central budget but 100 per cent of it was collected by the local organisations.

The contributions financed by the central budget included conditional and statutory subsidies. The role of the latter in local self-government financing further increased over the years. In addition, in the budget act the National Assembly laid down priority social objectives. The funds allocated for them were called "priority appropriations" and the local self-governments had a share in them in different forms year after year. In order to facilitate community convergence projects, a system of allocations and targeted financial support was set up. To avoid operational difficulties, the local self-governments that were disadvantaged for reasons beyond their control could request supplementary aid at tenders, and later on this was completed by support to inoperable local self-governments from the special budget of the Ministry of the Interior, up to 2011.

Concerning their financial management, local self-governments were allowed to take loans, with the condition that neither the core assets, nor the statutory state contribution, any other state aid, personal income tax and the funds received from the central budget for operation could not be used as collateral. Liquid loans, e.g. current account overdrafts, used for overcoming temporary liquidity shortages, were an exception to this. As a regulatory element, the debt service cap was 70 per cent of the annual appropriation for their own current income less the short-term liabilities (principal repayment and interest payment, lease fee) for the given year, in other words, the adjusted current revenues of their own [Article 88 (2) of the Act on Local self-governments]. The local self-governments were required to report the relevant data, but no effective penalty followed overspending, thus there was no supervisory organization that would have punished its violation. Only the State Audit Office was authorized to act, but typically, they did not take any action.

4 Based on Act C of 1990 on Local Taxes, still in effect.

5 The system of divided taxes also works in Slovenia: corporate income taxes are shared by the central and the local level, see Klun and Stambuk (2015) and Klun (2012). 
Important amendments after 1996 included codification of the debt management procedure (Act XXV of 1996 on the management of local self-government debts), and the specification of responsibilities, which provided that the municipal council must guarantee the safety of management and made the mayor accountable for compliance. As the purpose of the procedure was to restore the solvency of communities, it was a kind of a bankruptcy proceeding which was not allowed to result in the termination of the local self-government. The number of procedures barely exceeded a hundred between 1990 and 2010.

In addition to the creation of revenues and economic self-reliance, another means of restoring local self-governments' independence was the transfer of assets. Act XXXIII of 1991 assigned the assets previously owned by the state, including residential and non-residential property, listed historical buildings, protected natural areas, lands, public utilities, waters, public purpose water facilities, water utilities and other assets, into local self-government ownership. ${ }^{6}$

Thus the financial fundamentals provided the background for the creation of a public service organisation. The first act on local self-governments devolved the operation of the human infrastructure, with focus on public education and healthcare, to the competence of local self-governments among mandatory duties. The Hungarian system of local self-governments has been characterised by the fact that in addition to the said act, other statutes may also delegate tasks to and set quality requirements for local self-governments. This was called "task decentralisation" and at a later phase it led to problems as the delegation of tasks by the central organisations were not followed by the allocation of funds, neither in nominal nor in real terms, thus the budget deficit was shifted from the central government to the local and municipal system, and this is how the phenomenon of decentralised budget deficit evolved.

During elaboration of the system of tasks, numerous questions were left unanswered, e.g. the intermediate level regional governments remained weightless, and the public duties were not differentiated according to community size. The establishment of development regions, each comprising several county governments, was a preponderant event in the Hungary of the 2000s, but in the past decade they disappeared without trace.

Concerning its characteristic features, the Hungarian local self-government system simultaneously had the hallmarks of the Northern European and Southern European self-government models, as it imposed substantial duties on a fragmented system of local self-governments. Although encountering an increasing number of problems, this system proved to be sustainable up to Hungary's accession to the European Union, however, the period of abundant funds after the accession, or more specifically, the shortage or absence of funds required to pay their contribution as a precondition to drawing down EU funds brought them, somewhat paradoxically, to the brink of inoperability.

6 Act XXXIII of 1991 on the transfer of ownership of certain state-owned assets to local selfgovernments 


\section{The Hungarian local self-government system after hungary's accession to the European Union}

\subsection{The impact of accession to the European Union on the financial management of local self-governments}

After 2004, due to Hungary's accession to the European Union, the quality requirements set for the public duties of local self-governments tightened in order to improve the standard of public services used by the population and adjust them to that of the European Union. To this end, the quality parameters of human public services were stepped up, and the sectoral ministries required municipalities to implement increasingly large-scale plans. However, the problem was triggered by the fact that the budget acts ensured very little, if at all, of the funds required for the implementation of the more costly duties. This resulted in the rapid accumulation of an operating deficit the local self-governments found difficult to absorb.

The Convergence Plan, adopted in 2006 for the reorganisation of public finances that were out of balance, had a powerful impact on local self-governments' financial management, as it gave a greater role to municipalities in the provision of public services, merely to save money for the central budget. ${ }^{7}$ The reason for this was that prior to Hungary's accession to the European Union, the financial positions of the local self-government system had been relatively more favourable (than those of the central budget), however, there was an imbalance between the various local self-governments, as the positive balances were made primarily in bigger, well-industrialised cities, mainly those with county rights, while minor communities with hardly any revenues of their own and county governments made a loss. Thus, local self-governments' financial strength was erratic, but the duties were assigned indiscriminately, disregarding this fact. Local self-governments increasingly frequently used development funds and project loans to finance their operating expenses. As a result of the implemented task decentralisation and the failure to centralise funds, the decentralised government deficit and debt continued to increase, in other words, the potential deficit of the central budget was shifted to the orbit of local self-governments.

As a positive factor, with accession to the European Union access to development funds opened up. The resources available in the Cohesion and Structural Funds offered the prospect of considerable development potentials for municipalities. From the year 2004, local self-governments were granted significant amounts of development aids from the European Union and from domestic sources to provide the infrastructure background required for attendance to their responsibilities. With access to European aids, the regime of support to domestic development projects changed. In the first complete programming period, which began in 2007, the absorption of development

7 After 2002, Hungary's central budget underwent a drastic indebtedness process. By 2010, the government debt to GDP increased from 55 to 85 per cent. The budget deficit increment became permanent, and in 2006, prior to the adoption of the Convergence Plan, it exceeded 10 per cent. For further details see: Lentner, 2018. 
funds in an amount up to several orders of magnitude higher than the targeted subsidies financed from the Hungarian budget for capital formation in the previous 17 years.

However, the operational programmes of the 2007-2013 programming period frequently supported development projects that generated little or no additional revenue, and moreover, in many cases they triggered a sharp rise in operating expenses local self-governments often could not afford. Nevertheless, the main problem is that the local self-governments do not have sufficient resources for making the contribution required for access to the EU aids in order to support the implementation of their development tasks. As the EU funds encouraged important municipal investment projects, the local self-governments obtained the funds for the contribution required for access to them through loans and bond issuance, which led to the indebtedness of the local self-government system. For the most part, they used the EU aids and the loans they had taken for infrastructure improvement and other non-productive projects, thus no production or other coverage in real terms was created to subsequently finance debt service. In addition, local self-governments did not have any income in foreign currency to repay the loans, and thus they were grossly exposed to the foreign exchange rate and later on caused exchange rate losses.

\subsection{The impact of the economic crisis on Hungarian local self-governments - heading towards bankruptcy}

The 2007-2008 economic crisis and the increasing instability of the local selfgovernment system had a major impact on the complete system of public finances. ${ }^{8}$ Hungarian local self-governments' indebtedness accelerated after 2006, mainly due to the issue of foreign currency bonds, with the account managing banks typically acting as subscribers to the municipal bonds. This instrument was popular because it was not subject to any public procurement and the issuer local self-government could set the conditions in agreement with the account managing banks. As bond use was not limited by any target, and the requirements were very slight under weak state or EU control, most of the funds collected were used to repay previous debts or to finance operation, but a considerable part of the funds were not used at all, as they were time deposits for a specific purpose. Obviously, the predominant part of the revenues earned on the issuance of foreign exchange bonds, especially EU aids, was used for the specified purposes, however, these projects were frequently exaggerated and, more importantly, non-productive. With the escalation of the international financial crisis, the foreign exchange bonds issued for the implementation of non-productive projects imposed a significant debt service on local self-governments, which did not have any income in foreign currency, and thus in order to be able to repay they purchased foreign ex-

8 The 2011-2012 central budget balance, which was "working out all right", was deteriorated and the general government deficit was pushed above 3 per cent by the unfavourable developments in local self-government finances. Subsequently, however, the State Audit Office's audits regularly revealed the deficiencies in local self-government management, and various government decisions were taken as a result. 
change and consequently suffered grave losses, considerably deteriorating their liquidity, as despite its economic independence ensured since the 1990s, the Hungarian system of local self-governments had continuously struggled with liquidity problems. These problems were compounded by the fact that the local self-governments did not have sufficient operating income to continve the operation of most of the non-productive projects implemented from EU aids and foreign exchange denominated contribution (typically swimming pools, leisure centres and the renovation of public buildings). ${ }^{9}$ These items made the indebtedness of Hungarian local self-governments atypical.

In 2011 the audits performed by the State Audit Office revealed that the subsystem of local self-governments was financially unstable, and the collapse of self-governments may considerably the local provision of public services, and moreover, may even seriously undermine the complete system of public finances. As the local self-governments had no funds to repay the loans they had previously taken and to settle their bond-related debts, in 2011 the State Audit Office performed most of its audits in the system of local self-governments, as the latter had a grave impact on the complete regime of national public finances. Based on the State Audit Office's investigations it turned out that local self-governments' liquidity had considerably deteriorated between 2007 and 2010 because the system suffered a shortage of funds simultaneously for capital formation and for operation. The local self-governments' payment liabilities to banks increased and the liquidity loan agreements had to be regularly renewed with increasing credit lines. One of the reasons why this increasing debt portfolio grew into an enormous problem was that local self-governments failed to accumulate the reserves required for repayment, and they assumed a risk by offering local self-government core assets as coverage for loans. The State Audit Office shed light on the fact that in the case of the issued bonds, the potential unfavourable development in exchange rates was not the only problem, as their early redemption or conversion to Hungarian forints may lead to unexpected costs.

The local self-governments' exposure was further increased by rising accounts receivable outstanding and the growing financing gap, in other words, the absence of funds to finance the projects after their implementation using EU funds and to cover their operating costs. Due to the capital investments in progress, in late 2010, local self-governments' debt portfolio amounted to HUF 1154 billion (4.3 per cent of GDP produced in 2010), and external capital had to be raised in the amount of HUF 217 billion (0.8 per cent of GDP). Nevertheless, the projects had to be completed, as the local self-governments' infrastructure background was obsolete, and these projects increased the GDP output of the country, which was in crisis, and could ensure some employment. As an additional problem, the businesses in local self-government ownership also had a huge amount of debt, and thus the quality of the services they provided also "changeable", but in the absence of a statutory authorisation, the State Audit Office was not allowed to verify it before 2011, and consequently, no central action could be taken to return their business management to nor-

9 For details of the evaluation of local self-government project, see Vasvári (2013). 
mal. After 2011, the consolidation procedure was implemented on the basis of the State Audit Office's fact-finding investigation and recommendations targeted at putting local self-governments back on the right track. The State Audit Office's role increased both in the renewal of state management and in legislation (Domokos et al, 2016), which became a system-specific element in the Hungarian model of public finances, as it made the State Audit Office an active (supply) participant in good governance.

In the previous decades, the cause of the difficulty was the unsuitability of the regulatory and control environment for preventing and effectively keeping local self-governments' external fund raising under control. Although there was a limit set to debt in the system, it could not fulfil its purpose, as there had not been any authority to punish violation of the rules. Previously, the State Audit Office reported infringements, but it did not have the power to open a penal proceeding. As a result, the pressure of an increasing shortage of funds required for operation and capital formation and a spike in the foreign exchange rate brought the system on the verge of inoperability. This unfavourable process was ended by the action taken by the Hungarian public finance system and its institutions (including the State Audit Office), with statutory support and methodological confirmation. The macro-economic developments were also favourable: the government debt dropped by 30 per cent relative to GDP, the budget deficit has been below 3 per cent since 2013, the inflation rate is very slight and can be moderated, and all these are accompanied by the continuous increase in the gross domestic product (GDP). ${ }^{10}$

\section{The second act on local self-governments and the new regulatory environment}

The second act on local self-governments came into force in 2011 in several stages. During the elaboration of the legislation, efforts were made at the increased enforcement of the Charter and at preventing the curbing of the independence of local self-governments. The complete financing regime and the responsibilities were re-regulated.

The second Act on Local self-governments chopped tasks to reasonable sizes, and gradually re-centralised human public services (education and healthcare), leaving only a very slight amount of mandatory duties to be performed by local self-governments. Local self-governments' emphatic responsibilities include community operation and regional economy development, and the financing regime was adjusted accordingly. As less and minor duties were required of them, the role of central taxes given up in favour of local selfgovernments changed, and state aids were granted in the form of financing specific tasks, but this actually falls within the scope of statutory financing. Personal income tax was removed from among shared central taxes, in other words, its total amount is collected centrally, and the local self-governments'

10 2019. In Q1 it increased by 5.3 per cent, the highest rate in Europe. In the previous period which followed 2013, the gross domestic product increased by 3 to 5 per cent; and between 2010 and 2019, additional 750000 people have been involved in employment in a Hungary of 10 million, reducing the unemployment rate from 12.3 to 3.6 per cent in a decade. 
share in vehicle taxes was reduced to 40 per cent. In relation to local taxes, local self-governments' right to levy taxes was increased in addition to maintaining the previous framework regulation. The local self-governments were authorized to impose communal taxes on any object not yet locally or centrally levied. ${ }^{11}$ The responsibilities and competences of county governments were further reduced, which suggests continued reshaping in the Hungarian system of local self-governments.

According to Act XV of 1997, promulgating the European Charter of Local Self-Government, where public duties cannot be fulfilled in the given community, they must be performed by the public administrative organisation located closest to the citizens, the population. The second Act on Local selfgovernments allowed the establishment of shared local self-government offices, and after 2013, the communities with a headcount of 2000 or less and located in the same district were mandatorily required to set up joint municipal offices. The main purposes of establishing joint local self-government offices are the improvement of public duties and public services and to cut costs. On 1 January 2012, public county institutions and the healthcare institutions maintained by the Local self-government of Budapest were transferred to central maintenance, and on 1 May in the same year, the hospitals maintained by local self-governments were also taken over by the state. However, the reasonable streamlining and centralisation of local self-government responsibilities were not the only features that characterised the period that followed 2010, as the local self-governments' debts, which had turned to be unmanageable, also needed consolidation and centralisation.

\subsection{Debt consolidation}

After the entry into force of the new self-government rules, the economic policy regime made efforts at creating a stable environment for local selfgovernments. As the various local self-government segments encountered different problems, differentiated solutions were elaborated for them in regular consultation with the local self-governments. The reason for this is that similarly to the other countries of the European Union; in Hungary small-size communities have reduced financial capacities (de Vries-Sobis, 2019).

In the first round of consolidation, the total debts owed by county governments were consolidated. This is explained by the fact that in the absence of incomes of their own, they barely had appropriate coverage for repayment, and therefore county government debts and institutions were completely taken over by the state in 2012. This was followed by the transfer of debts owed by communities with headcounts above and below 5000 in two staged, in 2013 and 2014, respectively, and thus the total amount of debts outstanding on 31 December 2013 were assumed (Lentner, 2014). Financial consolidation is an unusual method in managing local self-government debt (which may well be termed the last resort), but it did also happen in Italy and Ger-

11 This considerably increased municipal independence in taxation, and taxes can be used for targeted taxes, social purposes or community development. 
many. The total consolidated amount was EUR 4.54 billion, representing 4.45 percent of GDP based on the 2014 data.

Table 1: The debt consolidation procedure

\begin{tabular}{lccc}
\hline Types of local self-government & Year & $\begin{array}{c}\text { Affected local self- } \\
\text { governments }\end{array}$ & $\begin{array}{c}\text { Consolidated } \\
\text { amount, EUR } \\
\text { billion }\end{array}$ \\
\hline $\begin{array}{l}\text { County governments } \\
\text { Communities with a headcount } \\
\text { below 5000 }\end{array}$ & 2012 & 20 & 0.69 \\
$\begin{array}{l}\text { Communities with a headcount } \\
\text { exceeding 5000 }\end{array}$ & 2013 & 1730 & 0.28 \\
$\begin{array}{l}\text { Consolidation of the remaining } \\
\text { portfolio }\end{array}$ & 2014 & 279 & 2.05 \\
\hline \begin{tabular}{l} 
Total \\
\hline
\end{tabular} & - & 511 & 1.52 \\
\hline
\end{tabular}

Source: The authors' compilation based on the specific data reported by the Hungarian State Treasury

Note: The data provided in Table 1 are calculated at the mean foreign exchange rate quoted by the National Bank of Hungary (at the end of the given year).

In order to prevent local self-governments from accumulating significant amounts of debt, numerous limiting factors and rules were introduced with the rules-based budget practice.

\subsection{Means to prevent repeated indebtedness}

In order to improve municipal management, which had been insufficiently regulated and controlled for decades, and to prevent the repeated evolution of the debt consolidation pressure, several limitations were imposed on local self-governments' financial independence, including their rights to establish companies and obtain participation in business organisations. ${ }^{12}$ Municipal self-governments may only participate in business organisations if the assets they contribute exceed their accountability (such include limited liability companies and company limited by shares). The fulfilment of their voluntarily undertaken duties and business activities may not prevent local self-governments from the performance of their mandatory duties.

12 Thus by placing independence in a reasonable frame, the new regulation intends to operate an economic policy and regulatory environment that can nip undisciplined, debt-generating management in the bud. Thus we hope to avoid the application of the pressure to consolidate debts. As described above, the consolidation pressure or the rescue, is already the outcome of a process. But in order to avoid using the central budget for a (repeated) rescue of organisations, poor management should be prevented by consistent regulation (for more details see: Lentner, 2015). 
Act on economic stability. ${ }^{13}$ As from 1 January 2012, the transactions that increase local self-government debts were limited at numerous points. Local self-governments are only allowed to take liquid loans for the purposes of ensuring their operation, i.e. they can only finance their deficit on operation from internal resources, and may not use external ones. Based on the statutory requirements that came into force in 2013, local self-governments are no longer allowed to schedule operating deficit at all. In addition, the Stability Act also stipulated that the payment liabilities due in the reporting year and arising from debt-generating municipal transactions may not exceed 50 per cent of their own revenues realised in the reporting year in any year up to the end of the term. This rule was intended to prevent local self-governments' running into insolvency. In addition, it was required that local self-governments may only perform debt-generating development and operation-related activities with the government's preliminary consent. Some of the loan transactions are, however, not subject to authorisation. These include loans to finance the contribution required for access to European Union development aids, and operating loans maturing within one year, as for the most part they leave the government debt measured against the Maastricht criteria unaffected. Furthermore, the transactions generating a debt below HUF 10 million, or in the case of Budapest and the cities with county rights, HUF 100 million, and the reorganisation loans used for the conclusion of agreements with creditors during debt consolidation.

After the settlement of responsibilities, the expenditures of Hungarian local self-governments dropped from 20 to 11-12 per cent within the total expenses of the general state budget (Sivák, 2005). Repeated municipal indebtedness is also prevented by a strict system of control, which includes regular central reviews, an internal audit system, ${ }^{14}$ and regular audits by the State Audit Office. After debt consolidation, local self-governments were required, with high priority, to prevent the increase of their debts, and to create their own operating balance to ensure the fulfilment of public duties. Although the foreign exchange loans taken by local self-governments have been assumed, the high debt owed by businesses in local self-government ownership continue to pose a risk for the municipal sector of public finances and indirectly, the complete general government. For this reason, the application of modern controlling instruments has an important role in ensuring stability (Zéman, 2017).

13 Act CXCIV of 2011

14 The audits of local self-governments' internal control systems, performed by the State Audit Office, are described in a 2014 study by Benedek et al. 
Figure 1: Distribution of Hungarian local self-government debts

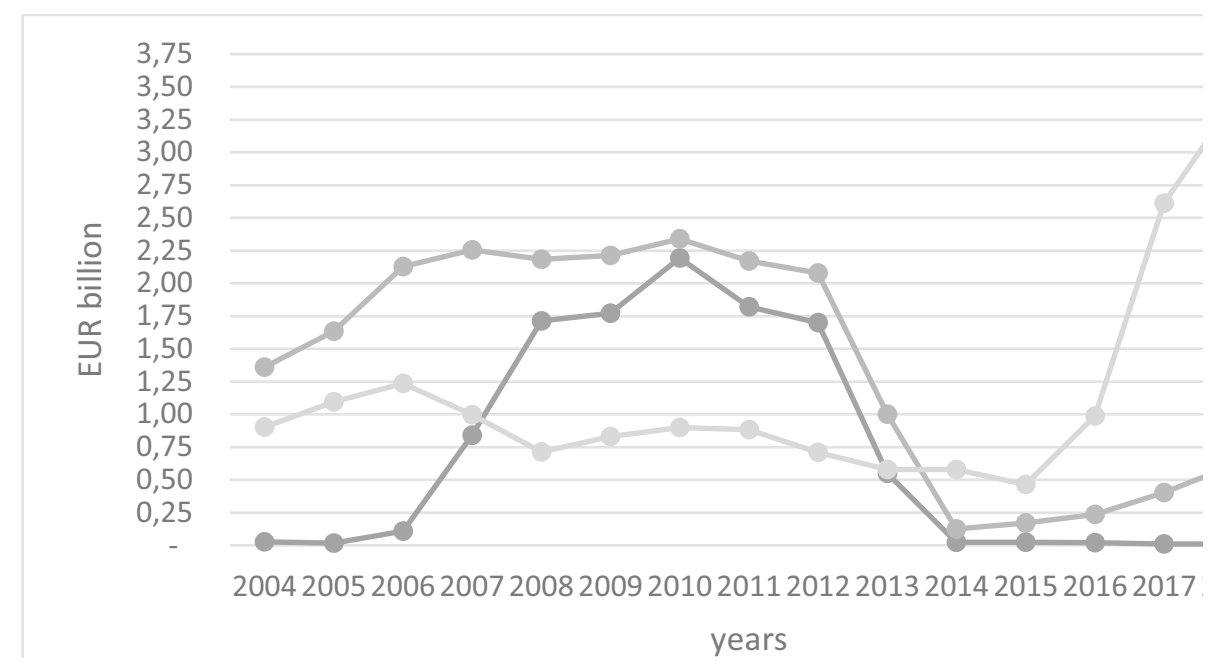

Source: National Bank of Hungary, 2019

After the debt consolidation, debts had slightly increased by 2018 according to the statistics of the National Bank of Hungary, mainly in the accounts receivable. However, the viability of the regulation is confirmed by the termination of financing via foreign exchange bonds, and thus the exposure to exchange rates no longer complicates management. Between 2017 and 2018, the ratio of long-term loans increased by approx. 75 per cent (to EUR 550 million), but this hardly represents 10 per cent of liabilities, considerably below the 2013 peak (preceding consolidation).

In contrast to the previous indebtedness, a significant ratio of the new loans finances projects that will generate additional tax revenues. Local self-governments frequently assume financing for terrain correction required for the resettlement of automotive factories, and later on these will provide coverage for repayment (from taxes levied and collected by the local self-government). The majority of other liabilities are accounts receivable, operative items related to capital investments, covered by current revenues, and thus not causing any liquidity problem. 
Figure 2: The official price of EUR and CHF to HUF

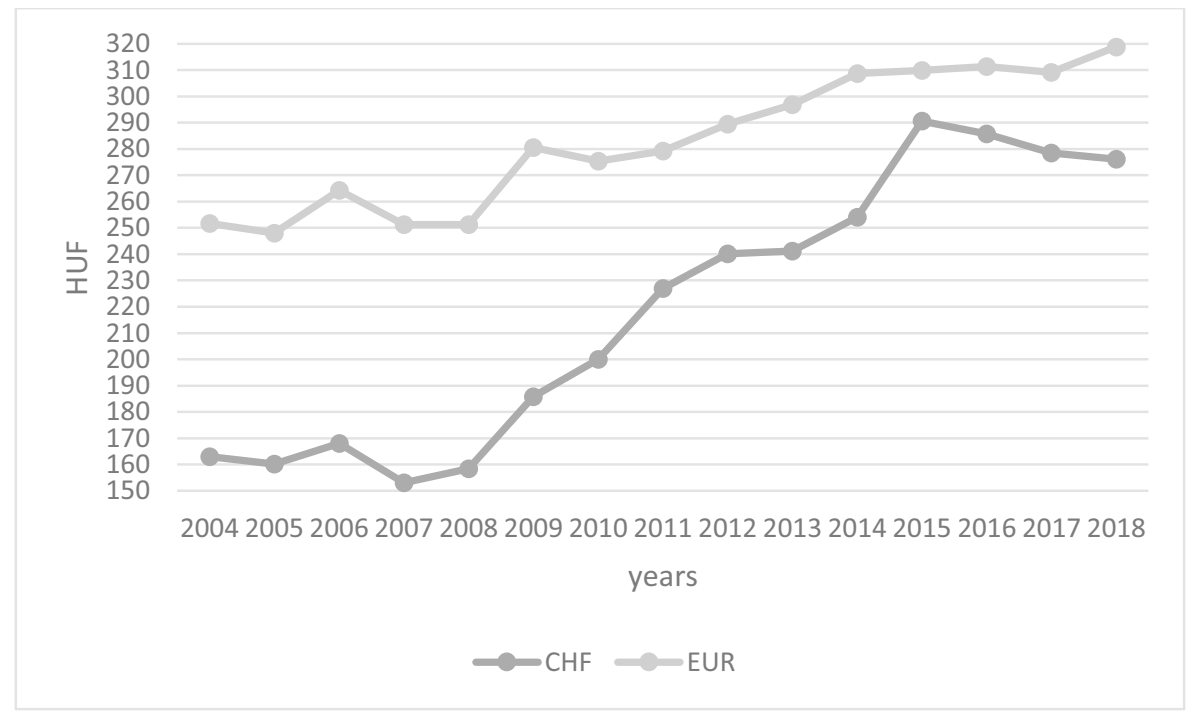

Source: National Bank of Hungary, 2019

One of the specific features of indebtedness by Hungarian local self-governments is that they issued bonds in foreign exchange, and thus they undertook long-term liabilities. As illustrated in Figure 2, this was a risky decision for local self-governments, as after the 2006-2008 wave of bond issues, the HUF exchange rate gradually weakened, and so they suffered a considerable exchange rate loss, representing an increase in the debt portfolio in the national currency (HUF). Changes in the exchange rates and their debt generating effects allow the conclusion that the consolidation of local self-governments' debt was justified, as the HUF rate to both CHF and EUR continued to weaken considerably during and after the consolidation. Local self-governments would have been incapable of absorbing these burdens as they did not have any incomes in foreign exchange, and the overwhelming majority of the capital investments implemented from bond revenues was unproductive, in other words, they did not have the capacity to generate yields. 
Figure 3: Distribution of Hungarian local self-government debts in foreign exchange

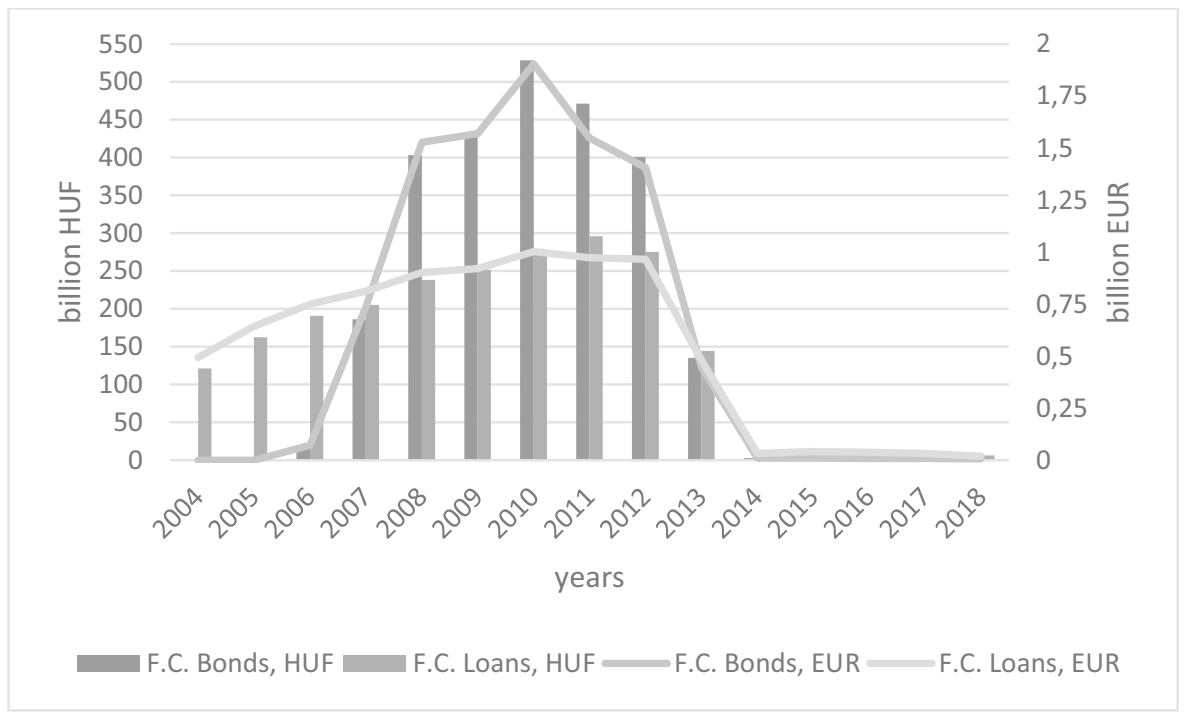

Source: National Bank of Hungary, 2019

Figure 3 clearly confirms that the instruments denominated in foreign exchange had a major role in the indebtedness of Hungarian local self-governments. The FX bond portfolio peaked in 2010 (recognised in HUF), while the FX loan portfolio reached its maximum in 2011. Presuming an unchanged portfolio, the exchange rate losses resulting from changes in the issue price had an impact of 12 per cent on the bond portfolio and of 8 per cent on loans, according to the authors' calculations.

\section{Hungarian local self-governments' indebtedness in an international comparison}

The grave indebtedness of Hungarian local self-governments and the central consolidation of their debts is an atypical phenomenon of the Central and Eastern European Region. No similar situation evolved in the surrounding countries. It should be emphasised that the countries participating in the Visegrád cooperation (V4) and Slovenia have similar histories, geographical sizes and development levels, and that Slovenia and Slovakia are members in the monetary union, thus they are protected against exchange rate fluctuations, and as an essential element, all the five countries reorganised their local self-governments in the spirit of the European Charter of Local Self-Government, but in Hungary, control was rather lenient in the two decades following the change of regime (Lentner et al. 2018). 
Figure 4: Distribution of long-term debts in a few countries of the post-soviet region

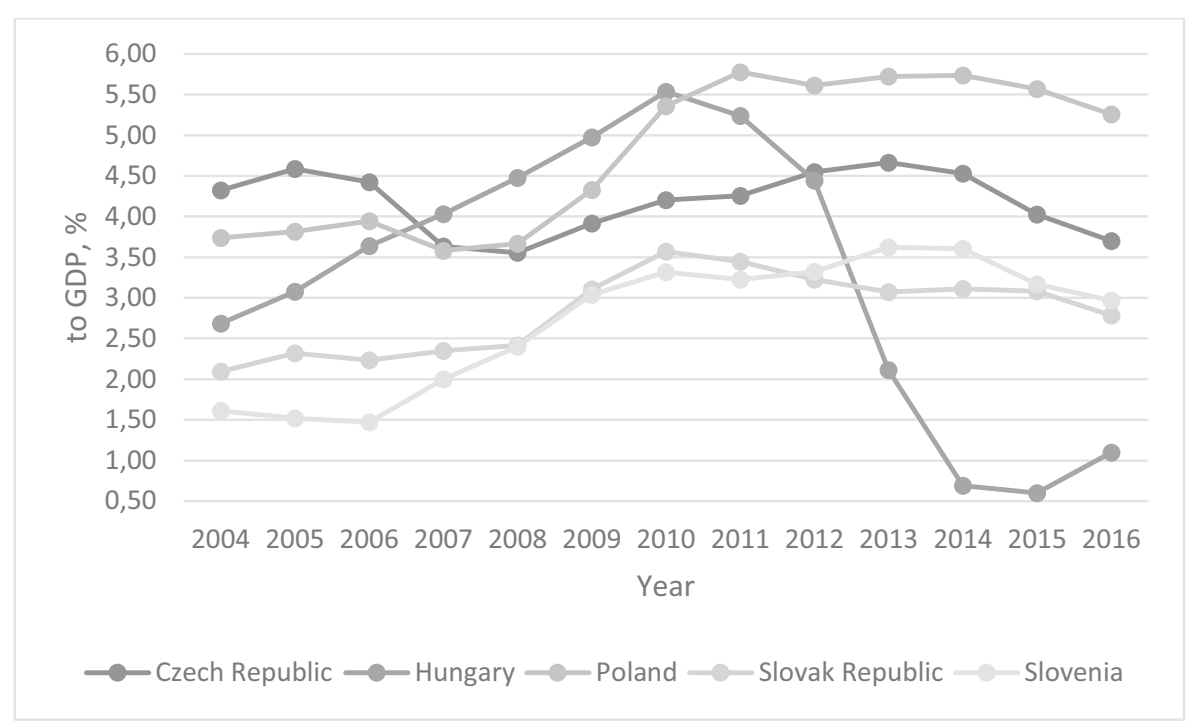

Source: OECD Fiscal Database, 2018

Figure 2 gives a comparison of local self-government debts to GDP in the Visegrád countries and Slovenia. Ever country is characterised by similar budgetary regulations applicable to local self-government operation in the period reviewed (Kotia and Lledó, 2016). The figure clearly shows that only Hungary is characterised by a sharp increase after the accession to the EU, while in the other countries the debt portfolio primarily increased in the period after the economic crisis. In the case of Slovenia, debts have been increasing since 2006, but were mitigated in the past few years. ${ }^{15}$ Debt to GDP started to fall in Hungary in the years of the crisis, from 2011. Next in the line was Slovakia, and then from 2014 local self-government debts began to decrease in the two other countries studied. Despite the fact that a new programming period of the EU started in 2014, this development continued till the end of the period. Hungary is the only exception, but this is due the fact that it started from a very low baseline after the debt consolidation, and to the perceptible and, more importantly, to a rise in short-term liabilities (cf. Figure 1 and Figure 2).

As a result of the global economic crisis, local self-government debt increased in every country of the world but the pace of growth in Hungary was unparalleled. Based on the trends the conclusion can be drawn that both local selfgovernments and the economic policy management were in favour of a stable and predictable debt portfolio, which is characteristic in every reviewed country in the post-soviet region after the crisis. As in the case of solvency the high-standard provision of public services is more likely, chances are better

15 About the implementation of duties by the Hungarian and Slovenian local self-governments, see Nagy et al. 2019. 
for compliance with the Charter if the economic fundamentals are stable and regulated.

\section{Conclusions}

Following Hungary's accession to the EU, its local self-governments encountered irreversible financial difficulties for a number of reasons. On the one hand, the sectoral policies raised the quality requirements of public services, and on the other, the restriction on central budget financing set out in the Convergence Plan adversely affected local self-governments. Following the evolution of an exchange rate boom during the crisis, the foreign exchange loans taken and the foreign exchange bonds issued for the contribution to the development funds that became accessible after accession to the European Union greatly increased the Hungarian local self-governments' burdens, however, they still needed the projects, as they had underdeveloped infrastructure.

The situation that had evolved by 2010 showed that the municipalities were incapable of paying their debt service, and so the economic policy leadership saw the re-regulation of responsibilities justified. This was accomplished by the renewal of the complete statutory regulation applicable to the field and by debt consolidation to solve atypical indebtedness; and simultaneously, a considerable part of the public duties assigned to local self-governments were decentralised. These factors were necessary for the safe operation of the economic fundamental that are indispensable for the provision of public services. After 2011 the political will gave green light to the required reforms, which were accomplished by changing the complex legislative environment.

Financial regulation tightened and the previous lenient regulation was replaced by more stringent calls to account and control, as is manifest in the legislative background and in the increasing control authorisations. The control functions of the State Audit Office and the government offices were enhanced: the former was authorised to check fulfilment of the economic requirements, while the latter verified compliance with the statutory regulations. In addition, the Hungarian State Treasury's supervisory powers have also increased: it is now authorised to impose sanctions. In the new system of public finance controls, the State Audit Office was assigned a particularly important role due to its prohibitive and guiding regulation and its proactive participation in legislation with the right to make proposals.

In the Visegrád countries and Slovenia, which have a past similar to Hungary, local self-government debt also decreased after the crisis, and this confirms the strengthening of predictable public finance regulation in the Central European region. In this process, Hungary was the first to make efforts at reducing municipal debts, however, after recovery from the crisis, every studied country followed a similar course, and this may contribute to the improvement of public services used in local communities, and thus serves the most effective possible enforcement of the European identity and of the Charter. 


\section{References}

Beck, W. A.-Stone, M. S. (2017). Why municipalities fail: Implications for uncertainty disclosures. Research in Accounting Regulation, 29 (1), pp 1-9.

Benčina, J. and Mrdža Kovačič, A. (2013). The Factor Model of Decentralization and Quality of Governance in European Union. International Public Administration Review, 11(3-4), pp. 57-79.

Benedek, M.; Szenténé Tubak, K. and Béres, D. (2014). Belső kontrollok a települési önkormányzatoknál (Internal controls at local governments). Public Finance Quarterly, 60(3), pp. 316-329.

de Vries, M. and Sobis, I. (2019). The Potential Capacity of Hamlets: Comparative Research on Small European Municipalities. Central European Public Administration Review, 17(1), pp. 199-220.

Cordes, T.; Guerguil,M.; Jaramillo, L.; Moreno-Badia,M.; Ylaoutinen, S. (2015). Subnational Fiscal Crises. In Designing a European Fiscal Union: Lessons from the Experience of Fiscal Federations; Carlo, C., Martine, G., Eds.; Routledge: London, UK; New York, NY, USA.

Domokos, L.; Várpalotai, V.; Jakovác, K.; Németh, E.; Makkai, M. and Horváth, M. (2016). Renewal of Public Management. Contributions of State Audit Office of Hungary to enhance corporate governance of state-owned enterprises. Public Finance Quarterly (61)2, pp. 185-204.

Gergely, J. (2005). Autonómiák in Hungary I-III. (Autonomies in Hungary I-III), Budapest, L'Harmattan.

Jacoby, M. B. (2016). Federalism form and function in the Detroit bankruptcy. Yale Joural of Regulation, 33(1), pp. 56-90.

Kornai, J. (2014). A puha költségvetési korlát. Kalligram Kiadó, Pozsony.

Kotia, A. and Duarte Lledó, V. (2016). Do Subnational Fiscal Rules Foster Fiscal Discipline? New Empirical Evidence from Europe. IMF Working Paper, 16/84.

Klun, M. (2012). Slovenian Income Taxes and Analysis of Their Tax Expenditure in 2006-2010. Financial theory and practice, 36 (3), pp. 229-243.

Klun, M. and Štambuk, A. (2015). Tax Experts' Opinion on the Tax System in Slovenia. eJournal of Tax Research, 13(3), pp. 784-798.

Lentner, Cs. (2014). The Debt Consolidation of Hungarian Local governments. Public Finance Quarterly, 59(3), pp. 310-325.

Lentner, Cs. (2015). The New Hungarian Public Finance System - in a Historical, Institutional and Scientific Context. Public Finance Quarterly, 60 (4), pp. 458-472.

Lentner, Cs. and Nagy L., Hegedűs Sz. (2018). Az önkormányzati feladatellátási-és finanszírozási rendszer szabályozásának összehasonlító elemzése Csehország, Szlovákia és Magyarország vonatkozásában-különös tekintettel a működésfenntarthatóság kérdésében. (A comparative analysis of the regulation of local governments' performance and financing in Czechia, Slovakia and Hungary, with special focus on operational sustainability) Miskolci Jogi Szemle, ("Legal Review of Miskolc", journal of the Miskolc University, Faculty of Law and Political Sciences), 13(2) pp. 17-38.

Lentner, Cs. (2018). Experts on New Hungarian State Finances from Legal, Economic and International Aspects. Pravni vjesnik: časopis za pravne i društvene znanosti Pravnog fakulteta Sveučilišta Josipa Jurja Strossmayera u Osijeku, 34(2), pp. 9-25. 
Nagy, M., Hoffman, I., Papp, D. et al. (2019). A Comparative Research on Municipal Voluntary Tasks of Three Hungarian and Slovenian Municipalities. Central European Public Administration Review, 17(1), pp. 165-197.

Sivák, J. (2014). Az önkormányzati rendszer rendszerelmélete (Systems theory of local governments. Public Finance Qarterly, 60(3), pp. 301-315.

Vasvári, T. (2013). Önkormányzati beruházások finanszírozása az európai uniós támogatások tükrében (Financing local government projects, in view of aid from the European Union). Statisztikai Szemle, 91 (2), pp. 1-5.

Vicente Lama, M., Cordobés Madueno, M., Torres Jiménez, M. (2017). To what extent should public corporations beconsolidated? Considering the effects on public deficit and debt in Spanish municipalities. Transylvanian Review of Administrative Science, 2017 (52), pp. 148-164.

Von Hagen, J., Bordignon, M., Grewal, B.S., Peterson, P., Seitz, H. (2000). Dahlberg, M. Subnational Government Bailouts in OECD Countries: Four Case Studies No. 3100. Research Department Publications from Inter-American Development Bank. At <https://ideas.repec.org/p/idb/wpaper/3100.html>, accessed 19 April 2019.

Umek, L. (2014). An Application of Subgroup Discovery Algorithm on the Case of Decentralization and Quality of Governance in EU. International Public Administration Review, 12(4), pp. 75-89.

Zéman, Z. (2017). The Risk-Mitigating Role of Financial Controlling at Local government Entities. Public Finance Quarterly, 62(3), pp. 294-310. 